\title{
FÚRÁSINDUKÁLT DELAMINÁCIÓ KIALAKULÁSA ÉS MÉRŐSZÁMAI SZÁLERŐSÍTETT POLIMER (FRP) KOMPOZITOKBAN
}

\section{FORMATION AND MEASURES OF DRILLING INDUCED DELAMINATION IN FIBRE REINFORCED POLYMER (FRP) COMPOSITES}

\author{
Geier Norbert ${ }^{1 *}$, Poór Dániel István ${ }^{1}$, Pereszlai Csongor ${ }^{1}$, \\ Bacs József ${ }^{1}$, Balázs Barnabás Zoltán ${ }^{1}$ \\ ${ }^{1}$ Gyártástudomány és -technológia Tanszék, Gépészmérnöki Kar, Budapesti Műszaki és \\ Gazdaságtudományi Egyetem, Magyarország \\ https://doi.org/10.47833/2021.1.ENG.005
}

\section{Kulcsszavak:}

Delamináció

Delaminációs faktor

Fúrás

Polimer kompozit

\section{Keywords:}

Delamination

Delamination factor

Drilling

Polymer composite

\section{Cikktörténet:}

Beérkezett 2021. január 13.

Átdolgozva 2021. március 30.

Elfogadva 2021. április 5.

\begin{abstract}
Összefoglalás
A szálerősített polimer (FRP) kompozitok kedvezőtlen technológiával történő megmunkálása során az FRP laminált rétegei elválnak egymástól, ezzel delaminációt (üreghibát) létrehozva, mely jelentősen csökkentheti a kompozit alkatrész eredő szilárdságát. Jelen áttekintő tanulmány fő célja az FRP kompozitok fúrása során kialakuló delamináció létrejöttének okainak és főbb mérőszámainak összegyüjtése, rendszerezése és kritikus értékelése.
\end{abstract}

\begin{abstract}
The laminated layers of fibre reinforced polymer (FRP) composites separate from each other and form delamination if the machining technology of FRP composites is unfavourable, which can significantly reduce the resulting strength of the composite part. The main goal of this review study is to collect, systematise, and critically evaluate the reasons and major metrics of drilling induced delamination of FRP composites.
\end{abstract}

\section{Bevezetés}

A szálerősített polimer (FRP) kompozitanyagok -jellemzően- kiváló fajlagos mechanikai tulajdonságai, jó méretstabilitásuk és korrózióállóságuk miatt egyre szélesebb körben alkalmazott szerkezeti anyagai a „high-tech” iparágaknak, úgy, mint a repülőgép-, ür-, gépjármü- és hadiiparnak [1]. Számos előnyös fizikai tulajdonságai és alkalmazási előnyei ellenére a szélesebb körü elterjedésüknek fő gátja a kiemelkedően bonyolult (gyakran részletes-optimalizált gyártási folyamattervezést igénylő) és magas gyártási költségeikben áll. Gyártásuk jellemzően egy műveletben történő készre laminálás, azonban számos esetben forgácsolni szükséges az elöírt méret-, alak- és helyzettürések ill. mikrogeometriai előírások elérése céljából. Az FRP kompozitanyagok anizotrop és inhomogén jellege, az erősítőszálak -gyakran- abrazív koptatóhatása és a polimer mátrix körülményes forgácsolhatósága miatt azonban a nehezen forgácsolható anyagok közé soroljuk öket [2]. Kedvezőtlen forgácsolástechnológiai körülmények

\footnotetext{
* Kapcsolattartó szerző. Tel.: +36 14632641

E-mail cím: geier.norbert@gpk.bme.hu
} 
esetében (pl. kedvezőtlen irányú és nagyságú forgácsolási erö, relatív nagy szerszám élsugár, nem megfelelően impregnált erősítőszálak) a laminált rétegek elválhatnak egymástól és úgynevezett delamináció, azaz üreghiba, avagy anyag diszkontinuitás keletkezik [3]. Ezen forgácsolásindukált delamináció -méretétől és helyzetétől függően- jelentősen csökkenti a kész FRP kompozit alkatrészek nominális szilárdságát. Az áttekintő cikk fő célja, hogy az FRP kompozit anyagok fúrása során képződő delamináció kialakulásának okait és mérőszámait összegyüjtse, rendszerezze, és alkalmazhatóságukat kritikusan értékelje.

\section{Delamináció kialakulása fúrásnál}

Amennyiben az FRP anyagok forgácsolása során a forgácsolási erő (i) kedvezőtlen irányban hat a laminált rétegekre, illetve (ii) egy kritikus értéknél nagyobb, úgy a kompozit anyag laminált rétegei szétválnak egymástól. Az így keletkező anyag diszkontinuitást (üreghibát) delaminációnak nevezzük [3]. A forgácsolási technológiát minden esetben úgy célszerü megtervezni, hogy a delamináció nagysága és kiterjedése minimális legyen, hiszen a nagyobb delamináció kisebb eredő kompozit mechanikai tulajdonságokat eredményez.

Fúrás során jellemzően a furat be és kilépő éleinél keletkezik számottevő delamináció, az 1. ábrán látható módokon. A csigafúró főéle az anyagba történő belépésekor felszakítja a felső laminált rétegeket, ezzel üreghibát okozva, ahogyan az 1. (a) ábrán látható. Ezt az üreghibát felhámozódó (peel-up) típusú delaminációnak nevezzük [3]. A csigafúró anyagból való kilépése előtt az utolsó laminált rétegeket kihajlítja, ezzel elválasztja őket a felettük lévő rétegektől, ahogyan az 1. (b) ábrán látható. Ezt az üreghibát kitoló (push-out) típusú delaminációnak nevezzük [3].

a) belépő delamináció

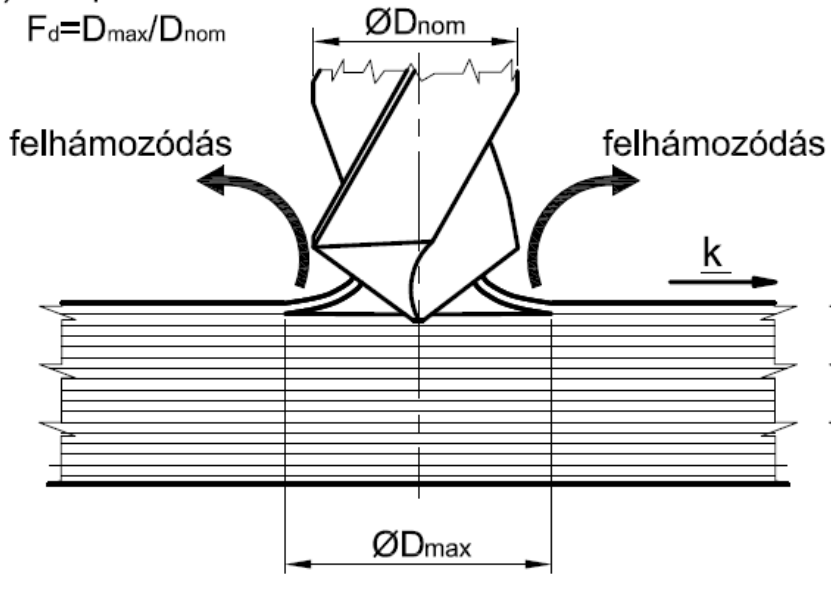

b) kilépő delamináció $F_{d}=D_{\max } / D_{\text {nom }}$

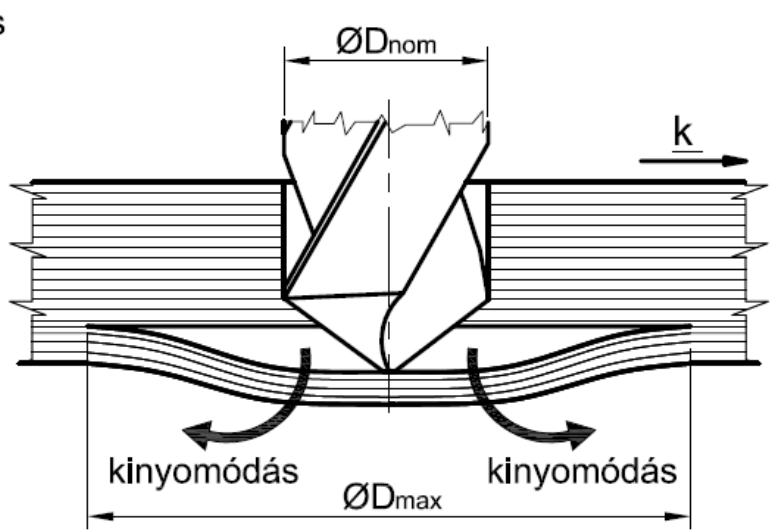

1. ábra. Sematikus ábra a FRP hagyományos fúrása során keletkező delamináció kialakulásáról: (a) „peel-up” típusú delamináció és (b) „push-out” típusú delamináció

A forgácsolási folyamatparaméterek hatását számos kutató vizsgálta már a delamináció nagyságára és/vagy kiterjedésére [3], azonban a delamináció mérési és/vagy kiértékelési módszerük gyakran csak körülményesen alkalmazható ipari környezetben. A delamináció mérhető és vizsgálható (i) digitális fénymikroszkóppal készített felvételek feldolgozásával [4], (ii) C-scannelt felvételek elemzésével [5] és (iii) abrazív visszafejtő eljárással [6].

\section{Fúrásindukált delamináció mérőszámai}

A delamináció számos paraméterrel jellemezhető, melyekkel leírható a delamináció (i) nagysága, (ii) kiterjedése, (iii) jellemző iránya és (iv) alakja. A nemzetközi tudományos szakirodalomban leggyakrabban alkalmazott delaminációs mérőszámok az 1. táblázatban láthatók összefoglalva, a mérőszámok generálásához szükséges jellemzők pedig a 2. ábrán vannak szemléltetve. A nemzetközi szakirodalomban a hagyományos delaminációs faktort $\left(F_{d}\right)$ 
alkalmazzák a legszélesebb körben a paraméter értelmezési és meghatározásának relatív egyszerüsége és gyorsasága miatt. Alkalmazásának jelentős korlátja, hogy a delaminált (sérült) terület sem alakját, sem méretét nem veszi figyelembe, csupán maximális kiterjedésének nominális furatátméröre fajlagosított értékét. A delaminált térség területét veszik figyelembe a $D F$, $F_{a}, F_{d a}, F_{e d}, F_{v}, F E E D, F_{D R}, F_{d f}$ és $F_{m d}$ paraméterek. Ezen mérőszámok értéke valamelyest korrigál a delaminációval terhelt alkatrész eredő szilárdságcsökkenésével, azonban a korreláció nehezen határozható meg egyértelműen. Nagarajan és mtsai. [17] különbséget tettek a súlyosan, közepesen és kevésbé roncsolódott furat körüli területek méröszámra gyakorolt hatásában, így különböző súlyokkal vették azt figyelembe. Sólyom [20] egy olyan delaminációs mérőszámot fejlesztett, melyben kombinálta a delaminált térség kerületének és területének fajlagosított méreteit.

A jelenleg alkalmazott mérőszámok jellemzően nem veszik figyelembe a delaminált kompozit szerkezet anizotropiáját: ugyan azon mérőszámot generálnak hasonló típusú, de eltérő rétegrendü vagy eltérő szálszerkezetü kompozitok esetében 


\section{Táblázat. Fúrásindukált delaminációt jellemző mérőszámok}

\begin{tabular}{|c|c|c|}
\hline Megnevezés (mértékegység) & Képlet & Hivatkozás \\
\hline $\begin{array}{l}\text { Hagyományos delaminációs } \\
\text { faktor (1) }\end{array}$ & $F_{d}=\frac{D_{\max }}{D_{\text {nom }}}$ & Chen [7] \\
\hline $\begin{array}{l}\text { Módosított delaminációs faktor } \\
(\%)\end{array}$ & $F_{d}^{\prime}=\frac{\left(D_{\max }-D_{\text {nom }}\right)}{D_{\text {nom }}} \%$ & Gaugel és mtsai. [8] \\
\hline Inverz delaminációs faktor (1) & $F_{d, i n v}=\frac{D_{n o m}}{D_{\max }}$ & Khanna és mtsai. [9] \\
\hline $\begin{array}{l}\text { Minimális delaminációs faktor } \\
\text { (1) }\end{array}$ & $F_{\text {dmin }}=\frac{D_{\text {min }}}{D_{\text {nom }}}$ & Da Silva [10] \\
\hline $\begin{array}{l}\text { Területalapú delaminációs } \\
\text { faktor }(\%)\end{array}$ & $D F=\left(\frac{A_{\text {del }}}{A_{\text {nom }}}\right) \%$ & Faraz és mtsai. [11] \\
\hline $\begin{array}{l}\text { Területalapú delaminációs } \\
\text { faktor (1) }\end{array}$ & $F_{a}=\frac{A_{\text {del }}}{A_{\text {nom }}}$ & Mohan és mtsai. [12] \\
\hline $\begin{array}{l}\text { Korrigált delaminációs faktor } \\
\text { (1) }\end{array}$ & $F_{d a}=F_{d}+\frac{A_{d e l}}{\left(A_{\max }-A_{\text {nom }}\right)} \cdot\left(F_{d}^{2}-F_{d}\right)$ & Davim és mtsai. [13] \\
\hline $\begin{array}{l}\text { Ekvivalens delaminációs faktor } \\
\text { (1) }\end{array}$ & $F_{e d}=\frac{\sqrt{\frac{4 \cdot\left(A_{d e l}+A_{\text {nom }}\right)}{\pi}}}{D_{\text {nom }}}$ & Tsao és mtsai. [14] \\
\hline $\begin{array}{l}\text { Háromdimenziós delaminációs } \\
\text { faktor (1) }\end{array}$ & $F_{v}=\frac{1}{p} \cdot \sum_{k=1}^{p} \frac{A_{d e l}{ }^{k}}{A_{\text {nom }}}$ & Xu és mtsai. [15] \\
\hline $\begin{array}{l}\text { Effektív egyenértékü } \\
\text { delaminációs faktor (1) }\end{array}$ & FEED $=\frac{\sqrt{\frac{4 \cdot A_{e}}{\pi}}+\frac{p_{e}}{\pi}}{2 \cdot D_{\text {nom }}}$ & Babu és mtsai. [16] \\
\hline $\begin{array}{l}\text { Finomított delaminációs faktor } \\
\text { (1) }\end{array}$ & $\begin{aligned} F_{D R}=\frac{D_{\max }}{D_{\text {nom }}}+1,783 \cdot \frac{A_{H}}{A_{\text {nom }}}+0,7156 \\
\cdot\left(\frac{A_{M}}{A_{\text {nom }}}\right)^{2}+0,03692 \cdot\left(\frac{A_{L}}{A_{\text {nom }}}\right)^{3}\end{aligned}$ & $\begin{array}{l}\text { Nagarajan és mtsai. } \\
{[17]}\end{array}$ \\
\hline $\begin{array}{l}\text { Sugáralapú delaminációs } \\
\text { faktor (1) }\end{array}$ & $R_{d}=R_{\max }-R_{n o m}$ & Khashaba [18] \\
\hline Delamináció körkörössége (1) & $F_{d f}=4 \cdot \pi \cdot \frac{A_{d e l}}{P_{e}^{2}}$ & Durão és mtsai. [19] \\
\hline Átlagos delaminációs faktor (1) & $F_{m d}=\frac{A_{d e l}+A_{\text {nom }}}{A_{\text {nom }}} \cdot \frac{P_{e}}{P_{\text {nom }}}$ & Sólyom [20] \\
\hline
\end{tabular}




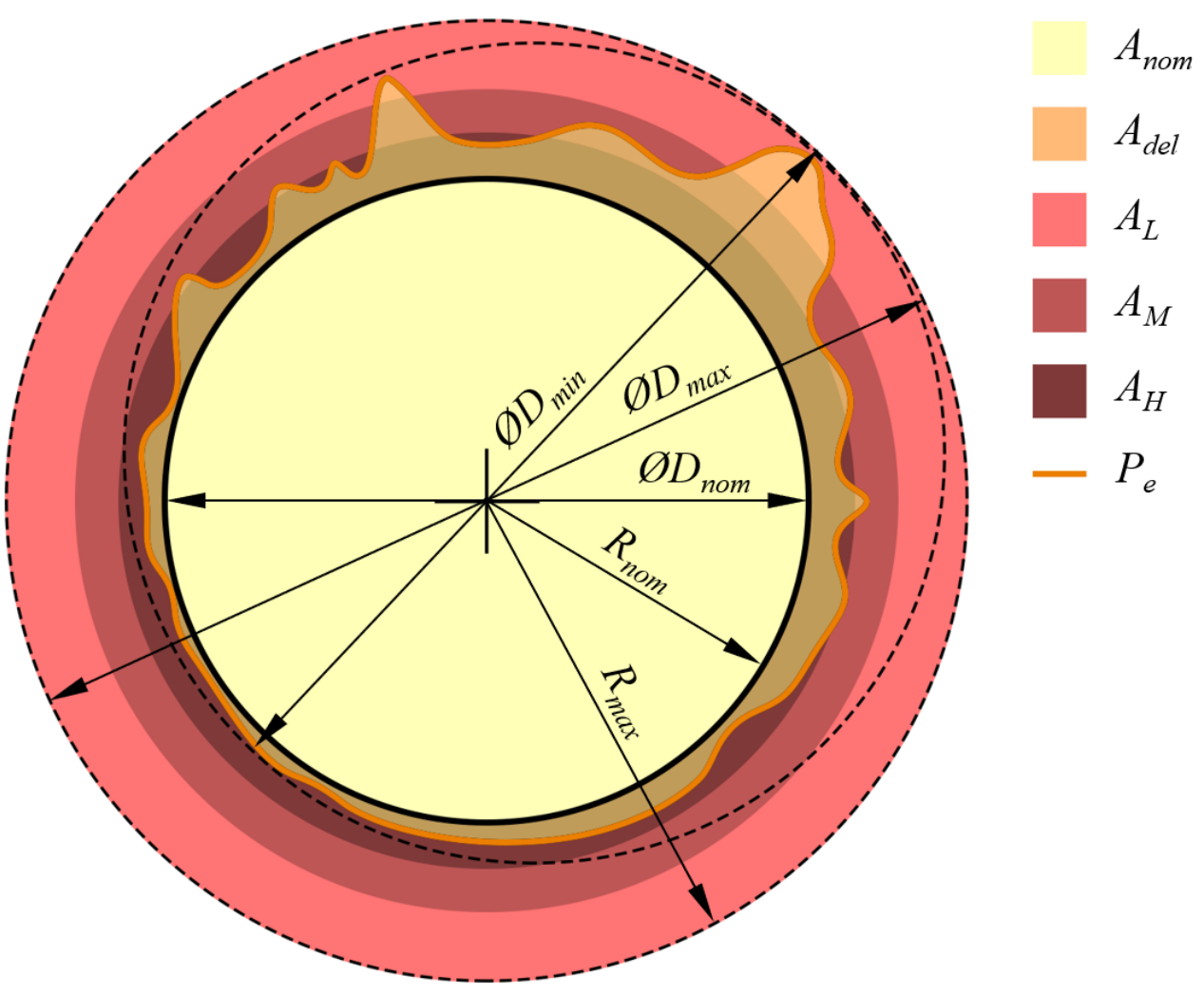

2. ábra. Sematikus ábra a delaminációs mérőszámokhoz kapcsolódó geometriai jellemzők értelmezéséhez, ahol $A_{\text {nom }}\left(\mathrm{mm}^{2}\right)$ a furat névleges területe, $A_{\text {del }}\left(\mathrm{mm}^{2}\right)$ a delaminációs terület, $A_{H}$

$\left(\mathrm{mm}^{2}\right)$ az eröteljesen delaminált terület, $A_{M}\left(\mathrm{~mm}^{2}\right)$ a közepesen delaminált terület, $A_{L}\left(\mathrm{~mm}^{2}\right)$ a

kevésbé delaminált terület, $P_{e}(\mathrm{~mm})$ a delaminált terület kontúrja, $P_{\text {nom }}(\mathrm{mm})$ a furat névleges

kerülete, $D_{\min }(\mathrm{mm})$ a delaminált térség köré írható kör átméröje, $D_{\max }(\mathrm{mm})$ és $R_{\max }(\mathrm{mm})$ a delaminált térség köré írható névleges furattal koncentrikus furat átméröje ill. sugara, $D_{\text {nom }}(\mathrm{mm})$ és $R_{\text {nom }}(\mathrm{mm})$ a névleges furat átmérője ill. sugara

\section{Fúrásindukált delaminációs mérőszámok tesztelése}

Az 1. táblázatban felsorolt delaminációs mérőszámok információtartalmát Davim és mtsai. [13] által publikált adatsoron teszteltük (3. ábra). A delaminációs mérőszám-számítási eredmények a 4. ábrán láthatók szemléltetve.

Fúrás; $\varnothing 5 \mathrm{~mm}$ K20 csigafúró; $v_{c}=60 \mathrm{~m} / \mathrm{min} ; 0 / 90^{\circ} \mathrm{CFRP}$;

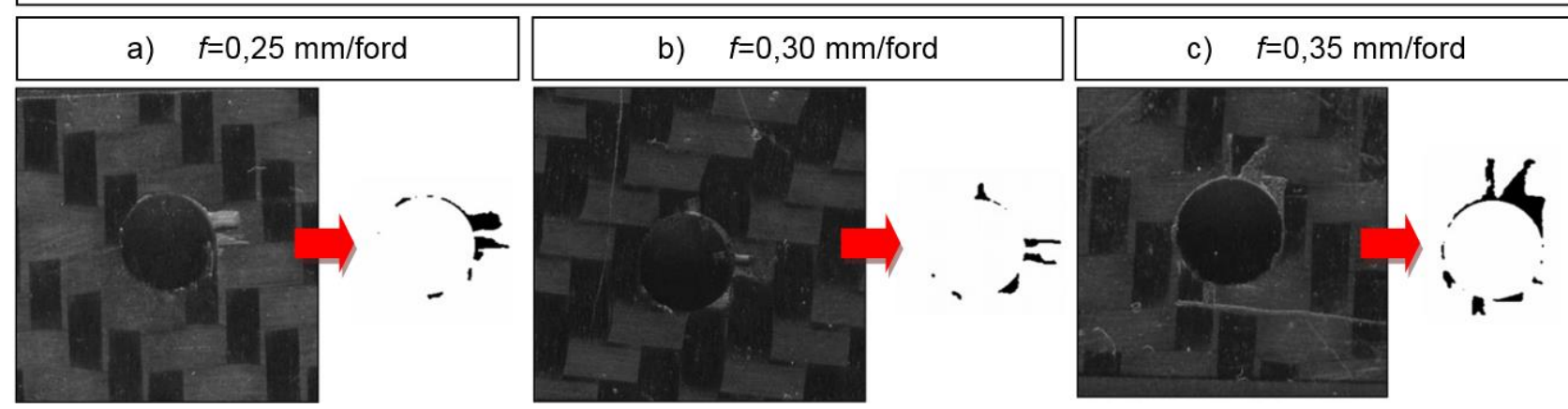

3. ábra. Davim és mtsai. [13] által publikált, K20 csigafúró felhasználásával fúrásindukált delaminációk kétirányban szénszállal erösített polimer (CFRP) kompozitanyagban, $v_{c}=60 \mathrm{~m} / \mathrm{min}$ :

(a) $f=0,25 \mathrm{~mm} /$ ford, (b) $f=0,30 \mathrm{~mm} /$ ford, (c) $f=0,35 \mathrm{~mm} /$ ford

Az elötolás növelésével a forgácskeresztmetszet növekszik, ami -konstans fajlagos forgácsolási erőt feltételezve- növekvő axiális irányú erőt eredményez, mely forgácsolási 
erökomponens felelős nagyrészt a „push-out” típusú delamináció kialakulásáért [21]. Ezzel összhangban a delaminált térség szemmel láthatóan növekszik az elötolás növelésével a 3. ábrán látható módon. Az ideális delaminációs mérőszámnak egy szükséges (de nem elégséges) feltétele, hogy képes legyen az elötolás-növelés negatív hatását számszerűen jelezni.

Az ábrán szemmel jól látható, hogy különböző mértékben roncsolódtak a forgácsolt furatok, azonban ezt a változást nem minden mérőszám képes kimutatni. Például: (i) $F_{m d}$ faktor hasonló értelemmel és tartalommal szolgáltat információt, mint a furatképek (ii) $F_{d f}$ faktor az előtolás ezen hatását nem képes statisztikailag kielégítő $(\alpha=0.05)$ módon jellemezni.

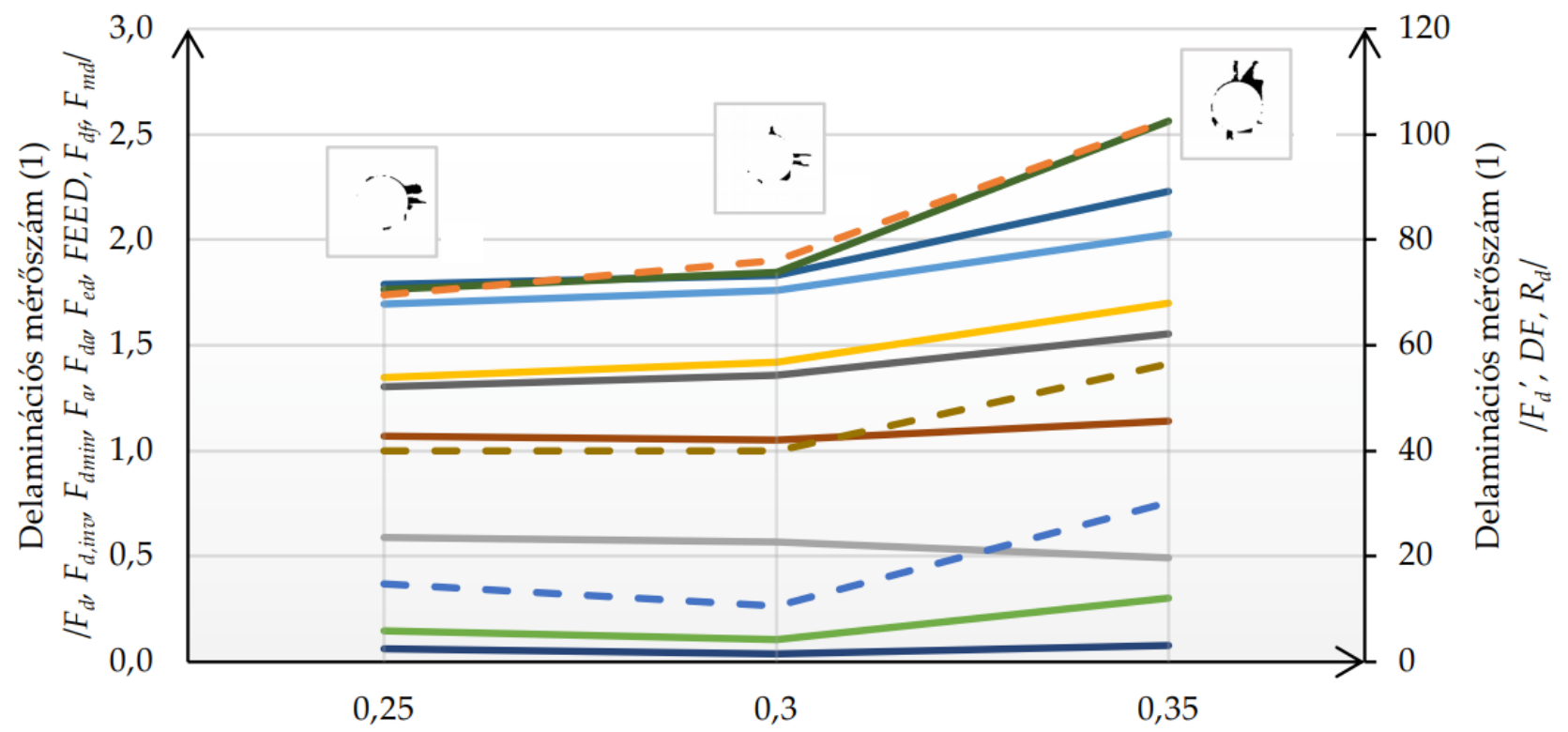

Előtolás (mm/ford)

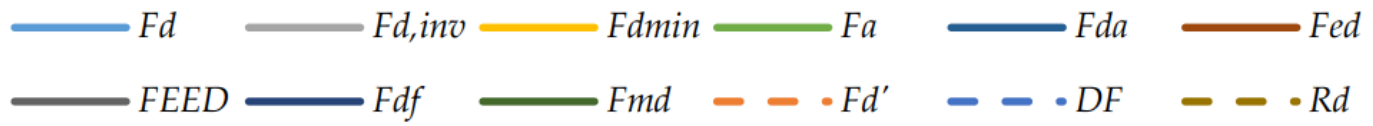

4. ábra. Delaminációs mérőszámok összehasonlítása CFRP kompozit $v_{c}=60 \mathrm{~m} / \mathrm{min}$ fúrása esetén

\section{5. Összefoglalás}

A nemzetközi szakirodalomban fellelhető fúrásindukált delaminációt jellemző mérőszámok többnyire a forgácsolt furat ideális-elméleti és a roncsolódott területének geometriai méreteinek kombinációjából épülnek fel. A hagyományos delaminációs faktor $\left(F_{d}\right)$ a legszélesebb körben alkalmazott mérőszám, mely a roncsolódott terület köré írt -nominális furattal koncentrikusmaximális körátmérő és a nominális körátmérő hányadosaként definiált egydimenziós mérőszám. $\mathrm{Az} F_{d}$ gyorsan és viszonylag egyszerüen számítható, azonban nem szolgáltat közvetlen információt sem a delaminált terület nagyságáról, sem alakjáról. Számos összetett delaminációs méröszámot javasoltak már a kutatók a delamináció jellemzésére, melyek többnyire geometriai megfontolásokon alapszanak, azonban a jelenlegi delaminációs mérőszámok egyikének nagysága sem korrigál ismert módon a delamináció okozta szilárdságcsökkenéssel, mely a további kutatások egyik fö irányát jelölheti ki.

\section{Köszönetnyilvánítás}

A kutatás részben az Innovációs és Technológiai Minisztérium OTKA-PD20-134430 kódszámú Posztdoktori Kutatási Projekt és az ÚNKP-20-3 és ÚNKP-20-2 kódszámú Új Nemzeti Kiválóság Programjainak a Nemzeti kutatási, fejlesztési és innovációs alapból finanszírozott támogatásával készült. A szerzők köszönik Sólyom Gellért irodalomkutatásban nyújtott segítségét. 


\section{Irodalomjegyzék}

[1] N. Geier, J. Paulo Davim, és T. Szalay, „Advanced cutting tools and technologies for drilling carbon fibre reinforced polymer (CFRP) composites: a review", Compos. Part A, köt. 125, o. 105552, 2019, doi: 10.1016/j.compositesa.2019.105552.

[2] J. Ahmad, Machining of Polymer Composites. Springer US, 2009.

[3] D. Geng és mtsai., „Delamination formation, evaluation and suppression during drilling of composite laminates: A review", Compos. Struct., köt. 216, o. 168-186, máj. 2019, doi: 10.1016/j.compstruct.2019.02.099.

[4] N. Geier, T. Szalay, és I. Biró, „,Trochoid milling of carbon fibre-reinforced plastics (CFRP)”, Procedia CIRP, köt. 77, o. 375-378, jan. 2018, doi: 10.1016/j.procir.2018.09.039.

[5] C. C. Tsao és Y. C. Chiu, „Evaluation of drilling parameters on thrust force in drilling carbon fiber reinforced plastic (CFRP) composite laminates using compound core-special drills”, Int. J. Mach. Tools Manuf., köt. 51, sz. 9, o. 740-744, szept. 2011, doi: 10.1016/j.ijmachtools.2011.05.004.

[6] H. Wang, J. Sun, J. Li, és W. Li, „Investigation on delamination morphology during drilling composite laminates”, Int. J. Adv. Manuf. Technol., köt. 74, sz. 1, o. 257-266, szept. 2014, doi: 10.1007/s00170-014-5973-6.

[7] W.-C. Chen, „Some experimental investigations in the drilling of carbon fiber-reinforced plastic (CFRP) composite laminates", Int. J. Mach. Tools Manuf., köt. 37, sz. 8, Art. sz. 8, 0 1997, doi: 10.1016/S0890-6955(96)00095-8.

[8] S. Gaugel és mtsai., „A comparative study on tool wear and laminate damage in drilling of carbon-fiber reinforced polymers (CFRP)", Compos. Struct., köt. 155, o. 173-183, nov. 2016, doi: 10.1016/j.compstruct.2016.08.004.

[9] N. Khanna, F. Pusavec, C. Agrawal, és G. M. Krolczyk, „Measurement and evaluation of hole attributes for drilling CFRP composites using an indigenously developed cryogenic machining facility”, Measurement, köt. 154, o. 107504, márc. 2020, doi: 10.1016/j.measurement.2020.107504.

[10] D. N. R. da Silva, „Image processing methodology for assessment of drilling induced damage in CFRP”, masterThesis, Faculdade de Ciências e Tecnologia, 2013.

[11] A. Faraz, D. Biermann, és K. Weinert, „Cutting edge rounding: An innovative tool wear criterion in drilling CFRP composite laminates", Int. J. Mach. Tools Manuf., köt. 49, sz. 15, Art. sz. 15, 0 2009, doi: 10.1016/j.jimachtools.2009.08.002.

[12] N. S. Mohan, S. M. Kulkarni, és A. Ramachandra, „Delamination analysis in drilling process of glass fiber reinforced plastic (GFRP) composite materials”, J. Mater. Process. Technol., köt. 186, sz. 1, o. 265-271, máj. 2007, doi: 10.1016/j.jmatprotec.2006.12.043.

[13] J. P. Davim, J. C. Rubio, és A. M. Abrao, „A novel approach based on digital image analysis to evaluate the delamination factor after drilling composite laminates”, Compos. Sci. Technol., köt. 67, sz. 9, o. 1939-1945, júl. 2007, doi: 10.1016/j.compscitech.2006.10.009.

[14] C. C. Tsao, K. L. Kuo, és I. C. Hsu, „Evaluation of a novel approach to a delamination factor after drilling composite laminates using a core-saw drill”, Int. J. Adv. Manuf. Technol., köt. 59, sz. 5, o. 617-622, márc. 2012, doi: 10.1007/s00170-011-3532-y.

[15] J. Xu, C. Li, S. Mi, Q. An, és M. Chen, „Study of drilling-induced defects for CFRP composites using new criteria”, Compos. Struct., köt. 201, o. 1076-1087, okt. 2018, doi: 10.1016/j.compstruct.2018.06.051.

[16] J. Babu, N. Paul Alex, S. P. Abraham, J. Philip, B. Anoop, és J. P. Davim, „Development of a comprehensive delamination assessment factor and its evaluation with high-speed drilling of composite laminates using a twist drill”, Proc. Inst. Mech. Eng. Part B J. Eng. Manuf., köt. 232, sz. 12, o. 2109-2121, okt. 2018, doi: $10.1177 / 0954405417690552$.

[17] V. A. Nagarajan, J. Selwin Rajadurai, és T. Annil kumar, „A digital image analysis to evaluate delamination factor for wind turbine composite laminate blade”, Compos. Part B Eng., köt. 43, sz. 8, o. 3153-3159, 0 2012, doi: 10.1016/j.compositesb.2012.04.013.

[18] U. A. Khashaba, „DELAMINATION IN DRILLING GFR-THERMOSET COMPOSITES”, Int. Conf. Aerosp. Sci. Aviat. Technol., köt. 10, sz. 10th International Conference On Aerospace Sciences\&Aviation Technology, o. 461481, máj. 2003, doi: 10.21608/asat.2013.24453.

[19] L. M. P. Durão, J. M. R. S. Tavares, V. H. C. de Albuquerque, és D. J. S. Gonçalves, „Damage evaluation of drilled carbon/epoxy laminates based on area assessment methods”, Compos. Struct., köt. 96, o. 576-583, 0 2013, doi: 10.1016/j.compstruct.2012.08.003.

[20] G. Sólyom, „Szénszállal erősített polimer (CFRP) kompozitok fúrásakor keletkező delamináció elméleti vizsgálata”, Budapesti Müszaki és Gazdaságtudományi Egyetem, Budapest, 2019.

[21] N. Geier és T. Szalay, „Analysis of the cutting forces in machining of uni-directional carbon fiber reinforced plastics (UD-CFRP)", Poceedings 7th Int. Technol. Conf. CVUT, 0. 42-46. 